Kinga Kaśkiewicz

Uniwersytet Mikołaja Kopernika, Toruń

e-mail: Kinga.Kaskiewicz@umk.pl

\title{
Pierwsze rozważania na temat koloru we Francji przełomu XVII i XVIII wieku
}

DOI: http://dx.doi.org/10.12775/RF.2018.011

Spór dotyczący ważności różnych środków wyrazu artystycznego w malarstwie: kolor czy linia rozegrał się dosyć niespodziewanie na spotkaniach w Królewskiej Akademii Malarstwa i Rzeźby w Paryżu pod koniec XVII wieku. Jednak jego konsekwencje miały swe echa jeszcze sto lat później i dotyczyły przede wszystkim sztuki malarskiej oraz przemiany sztuki klasycznej w romantyczną. Były one jednak widoczne nie tylko w krytyce sztuki, ale również w rozważaniach estetyki filozoficznej, u takich jej twórców, jak: Denis Diderot, Johann Wolfgang Goethe, a nawet Immanuel Kant.

Królewska Akademia Malarstwa i Rzeźby została powołana do życia w 1648 roku w Paryżu przez ministra finansów Colberta. Jednak dopiero od 1667 roku rozpoczęto szeroko zakrojony program spotkań, gdzie referowano teoretyczne aspekty sztuki oraz omawiano określone dzieła artystów nowożytnych ${ }^{1}$. Referaty, które były wygłaszane dwa razy $\mathrm{w}$ miesiącu zostały spisane i przygotowane do druku przez znakomitego estetyka, pisarza i architekta André Félibiena. Dzięki temu mamy możliwość bezpośredniego wglądu w poruszane ówcześnie zagadnienia i toczone wokół nich dyskusje. Podstawowym celem Akademii było wykazanie, że ranga malarzy, grafików i rzeźbiarzy jest równie wysoka jak poetów i muzyków, w konsekwencji zaś, że wszyscy wy-

1 Informacje za Teoretycy, historiografowie i artyści o sztuce 1600-1700, oprac. J. Białostocki, red. M. Poprzędzka, A. Ziemba, Wydawnictwo Naukowe PWN, Warszawa 1994, s. 426 oraz M. Rzepińska, Historia koloru w dziejach malarstwa europejskiego, t. 1, rozdz. VIII, Wydawnictwo Arkady, Warszawa 1989, s. 359 i nn. 
mienieni artyści są kimś więcej niż rzemieślnikami, w przeciwieństwie np. do farbiarzy, czy też wytwórców gobelinów. Drugim celem (mniej istotnym dla naszych rozważań) było ukazanie wspaniałości twórczości francuskich artystów, obok wysoko wówczas cenionej sztuki włoskiej.

Malarstwo, rzeźba i grafika (rytownictwo - jak wówczas mówiono) pracują w różnych materiałach i w odmienny sposób. Jak zatem znaleźć wspólne dla nich źródło? Oto problem, przed którym stanęli teoretycy tamtych czasów. Rozwiązanie w zasadzie było gotowe i stanowiło podstawę sztuki renesansu. Wszystkie te gałęzie sztuki łączy rysunek, który ma dwie funkcje. Po pierwsze, pozwala odwzorowywać naturę w sposób wierny, ale jednocześnie twórczy, czy też mądry. Po drugie, i ważniejsze, rysunek jest efektem wynikającym z twórczego, świadomego i intelektualnego procesu budowania kompozycji. Rysunek zatem jako kompozycja może być podstawą przyjęcia malarstwa, grafiki i rzeźby do dziedziny sztuki, a nie rzemiosła, wymagają one bowiem od artysty przede wszystkim pracy intelektualnej, a dopiero w drugim rzędzie umiejętności praktycznych, uczonych odtwórczo. Twórca jest artysta, gdy umie samodzielnie myśleć, komponować, tworzyć, a nie wówczas, kiedy biernie powtarza wyuczone schematy. W XVII wieku jest to ważny aspekt rozważań nad rozróżnieniem sztuki od rzemiosła, ponieważ nie ma jeszcze pojęcia sztuk pięknych ani zakresu ich dziedziny. Twórcą pojęcia sztuk pięknych był Charles Batteux, który dopiero w 1746 roku opublikował słynne dzieło Les Beaux-Arts réduirs à un même principe (Sztuki piękne sprowadzone do jednej zasady) ${ }^{2}$. Sprecyzował w nim to, co już dawno było uznane: sztuki rzemieślnicze tworzą dzieła ze względu na potrzeby fizjologiczne człowieka, sztuki piękne ze względu na potrzeby duchowe. Stolarz tworzy doskonałe krzesło, które odciąża nasz kręgosłup i sprawia fizjologiczną przyjemność naszemu ciału, malarz przedstawia naturę $\mathrm{w}$ taki sposób, aby obraz wpłynął na rozwój naszej wyobraźni, zmienił wrażliwość i pobudził moralnie oraz intelektualnie3.

Chociaż twórcy Królewskiej Akademii Malarstwa i Rzeźby nie dysponują jeszcze pojęciem i dziedziną sztuk pięknych, to wychodzą z takich samych założeń jak później Batteux. Sztuki te mają zadanie przede wszystkim pedagogiczne, a realizują je poprzez dobrze wymyślony temat i doskonale zbudowaną kompozycję, inspirowaną obserwowaną naturą i dziełami starożytnych. Wspólnym więc źródłem sztuk, które

2 C. Batteux, Les Beaux-Arts réduits à un même principe, Paris 1989. W języku polskim dostępne są tylko fragmenty: Ch. Batteux, Zasady literatury, przeł. M. Walecka-Garbalińska, w: Europejskie źródła myśli estetyczno-literackiej polskiego oświecenia. Antologia wypowiedzi pisarzy francuskich, niemieckojezzycznych i angielskich 1674-1810, oprac. T. Kostkiewicz i Z. Goliński, Wyd. Naukowe Semper, Warszawa 1997, s. 232 i nn.

3 Por. K. Kaśkiewicz, Wptyw francuskich estetyków naturalistycznych osiemnastego wieku na klasyczna estetykę niemiecka, Wydawnictwo Naukowe UMK, Toruń 2010, rozdz. III, s. 141 i nn. 
dziś określamy mianem plastycznych jest umiejętność rysowania. Podstawowym tematem jest zaś przedstawianie ciała, a za jego pośrednictwem także duchowości ludzkiej. Uważano bowiem, że człowiek jest najdoskonalszą istota, jaką udało się stworzyć naturze, niezwykle skomplikowaną i różnorodną. W estetyce XVIII wieku często zauważano, że piękno i użyteczność w rzeczach naturalnych idą ze sobą w zgodzie podczas, gdy w tworach człowieka rzadko zachodzi takie współbrzmienie tych wartości. Tak jest na przykład w rozważaniach Williama Hogartha, czy Edmunda Burke'a ${ }^{4}$. Cały układ naszego organizmu został ukształtowany w taki sposób, abyśmy mogli wykonywać najróżniejsze funkcje, w różnorakich warunkach i sytuacjach. Ta różnorakość budowy i wewnętrzna celowość jest dla artysty niezwykle ciekawym tworem do naśladowania. Bogactwo i różnorodność zewnętrznej organizacji naszego ciała daje twórcy największe możliwości przedstawienia piękna. To właściwie owe nieograniczone możliwości podejmowania interesujących tematów i układów kompozycji stają się podstawą dobrej sztuki. Problematykę tę najwyraźniej przedstawił chyba William Hogarth w Analizie piękna, kiedy pisał:

Dodamy jednak gwoli sprawiedliwości, że ani jednak żywa istota nie jest zdolna do wykonywania tak zróżnicowanych ruchów i do czynienia tego $\mathrm{z}$ takim wdziękiem, z jakim robi to gatunek ludzki, a podnoszenie niedoścignionego piękna człowieka w dziedzinie kształtu i konstytucji również wydaje się oczywiste. Ponadto po tym, co już zostało powiedziane na temat kształtu i ruchu, jasne jest i całkiem bezsporne, że natura tak to sobie umyśliła, by piękno proporcji i piękno ruchu uczynić wzajemnie nierozłącznymi, zatem powyższe uwagi na temat zwierząt pozostają prawdziwe w stosunku do ludzi. Oznacza to, że osoba, której figura cieszy się najwyborniejszymi proporcjami, wykazuje największą zdolność do wykonywania najbardziej wyszukanych ruchów, pełnych swobody iwdzięku zarówno w sposobie codziennego poruszania się, jaki w tańcu ${ }^{5}$.

Przedstawiając materię ciała ludzkiego: poruszenia, gesty, mimikę, odcienie skóry artysta ma możliwość oddania jednocześnie ludzkiego ducha i może poprzez nie opowiadać o wspaniałych, wielkich, podniosłych czynach człowieka, które mogą stać się rozwojem kolejnych pokoleń. Dlatego najważniejszymi tematami malarstwa były doniosłe wątki historyczne, mitologiczne, religijne i alegoryczne. Wierzono, że wznio-

4 Por.: W. Hograth, Analiza piękna, przeł. M. Lachman, Wydawnictwo słowo/obraz terytoria, Gdańsk 2008 oraz E. Burke, Dociekania filozoficzne o pochodzeniu naszych idei piękna i wzniosłości, przeł. P. Graff, Wydawnictwo PWN, Warszawa 1968.

5 W. Hogarth, Analiza piękna, przeł. M. Lachman, Wydawnictwo słowo/obraz terytoria, Gdańsk 2008, s. 123-124. 
sła treść najmocniej pobudza wyobraźnię odbiorcy, silnie i długofalowo wpływa na jego wrażliwość, a przede wszystkim rozbudowuje zdolności etyczne i intelektualne. Zachwyt nad obrazem przedstawiającym bukiet kwiatów, nawet najpiękniejszych i najkunsztowniej odmalowanych, zawsze jest krótkotrwały, bo porusza tylko niektóre partie naszego ducha. Dopiero rozbudowana kompozycja odwołująca się do majestatycznej i podniosłej tematyki pobudza w nas przyjemność nie tylko estetyczna, ale i etyczną. $W$ ten sposób uczucia powstałe $w$ duszy widza są głębsze i trwalsze, bo łączą z sobą przyjemność estetyczną, doznania moralne i rozważania rozumowe. Jean-Baptiste Dubos, rozważając związki pomiędzy różnymi rodzajami sztuk a zdolnością ich do wzbudzania w nas silnych i trwałych uczuć, zauważa:

Sztuka malarska jest tak trudna, atakuje nas poprzez zmysł, którego oddziaływanie na duszę jest tak silne, że obraz może się podobać dzięki samym tylko urokom wykonania, niezależnie od przedmiotu, który przedstawia; ale jak już mówiłem, nasza uwaga i uznanie skupiają się wtedy tylko na sztuce naśladującego, która potrafi się podobać, nawet jeśli nie wzrusza. Badamy, jakimi sposobami operował malarz, by tak zwieść oko, żeby w farbach położonych na płaskiej powierzchni widziało ono prawdziwe owoce. Malarz może więc uchodzić za znakomitego rzemieślnika jako wykwintny rysownik albo jako kolorysta idący w zawody z natura, a jednak nie potrafiłby wyzyskać swoich talentów do wyobrażenia przedmiotów wzruszających, do włożenia w obrazy duszy i nadania im prawdopodobieństwa, jakie wyczuwamy w obrazach Rafaela czy Poussina ${ }^{6}$.

Sposób przedstawienia właściwy geniuszom, według francuskiego estetyka, wymaga przede wszystkim zdolności wybrania właściwego tematu, przemyślenia najlepszej kompozycji, doboru odpowiednich modeli i umiejętności przedstawienia ich mimiki, gestykulacji i sugestii ruchu. Jego poglądy nie były odosobnione w estetyce XVIII wieku. Wszystko to dostępne jest tylko dla ludzi, którzy w doskonały sposób opanowali rysunek. Przyjemności wynikające z powabu koloru nie tylko są pomijane, ale wydają się małe i błahe przy tak wzniosłych celach.

Podkreślano ponadto, że do opanowania rysunku potrzebne są nie tylko umiejętności praktyczne, ale przede wszystkim wiedza i rozum zdolny do pojęcia regut, na których opiera się optyka, a wraz z nią perspektywa. Wiedza ta zaś w znacznej mierze zasadza się na teoretycznych rozważaniach matematycznych. Kolor natomiast nie jest związany z żadnymi regułami, których opanowanie byłoby niezbędne, aby być do-

6 J.-B. Dubos, Refleksje krytyczne o poezji i malarstwie, przeł. A. Morawińska, w: Europejskie źródta myśli estetyczno-literackiej polskiego oświecenia. Antologia wypowiedzi pisarzy francuskich, niemieckojęzycznych i angielskich 1674-1810, oprac. T. Kostkiewicz i Z. Goliński, Wyd. Naukowe Semper, Warszawa 1997, s. 129. 
brym kolorystą. Wręcz przeciwnie: podkreślano, że w przypadku sztuki koloru nie ma żadnych reguł, a wielcy mistrzowie tacy, jak np. Tycjan, rodzą się rzadko, nie potrzebują i wcale nie posiadają specjalnej wiedzy. Umiejętności posługiwania się kolorem nabywa się przez praktykę, przez bierne naśladowanie mistrza lub obserwację natury. Nie mówimy tutaj o zdobywaniu wiedzy, ale o biegłości, nie jest to zatem umiejętność artystyczna, ale rzemieślnicza. To właśnie zdolność rysowania jest tym, co odróżnia artystę od rzemieślnika, a nie umiejętność kolorowania, właściwa malarzom pokojowym i farbiarzom. Wystarczy wspomnieć pełne złośliwości komentarze pod adresem francuskiego malarstwa wyrażone przez jednego z teoretyków sztuki związanego z Akademią Roberta Fréart de Chambray. W rozprawie zatytułowanej Idee doskonałego malarstwa wydanej w 1662 roku pisze o francuskim malarstwie, że jest to „sztuka libertyńska, która zważa tylko na szminkę koloru, aby zadowolić powierzchowne spojrzenie" 7 .

Zagadnieniom związanym z kolorem przeznaczono zatem bardzo dalekie miejsce $\mathrm{w}$ praktyce artystycznej i w teoretycznych rozważaniach toczących się w salach Królewskiej Akademii Malarstwa i Rzeźby. Wygłaszane tam referaty rozważające teoretyczne problemy albo analizujące działa wielkich artystów najczęściej skupiały się na zagadnieniach ściśle związanych z optyką i geometria, pochwała „idealnego piękna” antycznych posągów, a także z doborem tematów godnych twórczości artysty. Aby uzmysłowić sobie, jak wyglądała taka analiza dzieła, warto zajrzeć choćby do wykładu malarza i rysownika Charlesa Le Bruna wygłoszonego w Królewskiej Akademii 5 listopada 1667 roku, poświęconego malarstwu Poussina. Prelegent omawia w nim zagadnienia układu całości oraz poszczególnych grup postaci, następnie porusza kwestie rysunku i proporcji ciał, potem przedstawione przez te postacie emocje, dalej perspektywę przestrzenną i powietrzna, a na koniec dopiero wspomina o harmonii kolorów ${ }^{8}$ i jest to tylko niewielki dwuzdaniowy akapit, który pozwolę sobie tutaj zacytować:

Ponieważ kolor żółty i niebieski mają najwięcej udziału w [barwach] światła i powietrza, p[an] Poussin ubrał swe główne postacie w materie żółte i niebieskie, zaś do barw wszystkich innych draperii domieszał nieco tych dwóch głównych kolorów, osiągając to, że nade wszystko domi-

7 R. Fréart de Chambray, Idée de la perfektion de la peinture, Le Mans 1662. Cytat za: M. Rzepińska, Historia koloru w dziejach malarstwa europejskiego, t. 1, rozdz. VIII, op. cit., s. 360 .

8 Por. [Charles Le Brun] Szósty wykład, wygłoszony w Królewskiej Akademii Malarstwa i Rzeźby w sobotę, 5 listopada 1667, w: Teoretycy, historiografowie i artyści o sztuce 1600-1700, op. cit., s. 531. 
nuje tam kolor żółty, bo światło rozproszone w jego obrazie jest bardzo żółtawe?.

Aby oddać sprawiedliwość analizie dokonanej przez Le Bruna, trzeba wspomnieć, że o kolorycie mówi też jako o składowej odmalowywania emocji w obrazie. Ten sposób traktowania zagadnień kompozycji koloru jest charakterystyczny także dla innych referatów wygłaszanych w Królewskiej Akademii. Trzeba również przyznać, że choć podziwiano koloryt Tycjana, Giorgione czy Rafaela, to jednocześnie omawiano raczej kompozycyjne walory ich dzieł. Co ciekawe, przy omawianiu prac malarskich posługiwano się ich bezbarwnymi rycinami, co nie przeszkadzało rozprawianiu o kolorystyce ${ }^{10}$.

Dzięki protokołom z wystąpień w Królewskiej Akademii Malarstwa i Rzeźby oraz opublikowanemu w 1668 roku przez Félibiena dziełu Confèrences de l'Académie de Royale pour l'année 1667 możemy prześledzić bardzo dokładnie spór pomiędzy zwolennikami rysunku i koloru w tamtych czasach. Jak już zauważyłam, kwestie koloru zajmowały dalekie pozycje w hierarchii środków wyraz artystycznego. Dlatego też początkowo zagadnienia te poruszane były bardzo rzadko i stanowiły tylko rozważania poboczne. Zwracano co prawda uwagę na to, że kolory mają zdolność oczarowywania ludzkich oczu, roztaczają swoistego rodzaju urok, dzięki któremu przyciągają widza ku obrazom, jednak najwyżej ceniony był sposób skomponowania tematu, zdolny pobudzić rozum do refleksji i skłonić nas do rozważań moralnych. Kolor był wręcz moralnie podejrzany, pełen uroku, zaczarowywał, przyciągał bez zrozumiałego powodu, budził emocje, rozprzęgał dyscyplinę umysłu. Jeszcze pod koniec XVIII wieku podobne zdanie będzie wyrażał Immanuel Kant w Krytyce władzy sadzenia.

Sąd smaku jest więc tylko o tyle czysty, o ile determinująca go racja nie zawiera domieszki upodobania empirycznego. To zaś zachodzi zawsze, gdy w sądzie, za pomocą którego coś ma być uznane za piękne, biorą udział powab lub wzruszenie ${ }^{11}$.

Sąd o pięknie, żeby był właściwy, musi być, zdaniem Kanta, bezinteresowny. Nie może go zatem „zanieczyszczać" żadna domieszka czegoś, co byłoby prywatnym upodobaniem, opartym na indywidualnym doświadczeniu, odczuciu czy osobistej fizjologii. Upodobanie do takiej czy innej barwy jest takie samo jak pociag do takiego, a nie innego wina,

9 Ibidem, s. 542.

10 Por. C. Goldstein, Studies in Seventeeth Century French Art Theory and Ceiling Painting, "Art Bulletin” 1965, vol. 47, nr 2, s. 231-256.

11 I. Kant, Krytyka władzy sądzenia, przeł. M. Żelazny, w: idem, Dzieła zebrane, t. IV, Wydawnictwo UMK, Toruń 2014, s. 93. 
czy skłonność do tej lub innej potrawy. Tego typu zamiłowania są całkowicie subiektywne i nie mogą rościć pretensji do bycia powszechnymi, a ewentualna zgodność tego typu sądów stanowi czysty przypadek. Czysty sąd smaku może dotyczyć tylko kompozycji. $Z$ tego powodu Kant zauważa dalej:

Przeciw [takiemu stanowisku] wysuwane są różne zarzuty, które w ostatecznej konkluzji usiłują przedstawić powab nie tylko jako konieczny składnik piękna, lecz nawet jako coś, co samo w sobie dorasta do nazwania go pięknym. Wielu już sam kolor, np. zieloną barwę trawy, albo sam jakiś dźwięk, np. dźwięk skrzypiec (w odróżnieniu od hałasów i szmerów), uznaje za piękny sam w sobie, chociaż wydaje się, że u podstawy zarówno jednego, jak drugiego, leży tylko materia przedstawień, a mianowicie wyłącznie odczucie, że z tego względu zasługują one jedynie na nazwę przyjemnych. Równocześnie jednak każdy zauważy, że zarówno wrażenie barwy, jak i dźwięku tylko o tyle mogą pretendować do tego, by być uznane za piękne, o ile są czyste. To zaś jest już określeniem [Bestimmung] dotyczącym formy, a zarazem w owych przedstawieniach jest czymś jedynym, co na pewno może udzielać się powszechnie. Trudno byłoby bowiem przyjąć, by sama jakość odczuć była we wszystkich podmiotach taka sama i by każdy w taki sam sposób oceniał jakąś barwę i dawał pierwszeństwo [płynącej z niej] przyjemności nad [przyjemnością płynącą] z innej barwy czy też dźwiękowi pewnego instrumentu muzycznego [przypisywał pierwszeństwo] przed innym ${ }^{12}$.

Królewiecki filozof swoją krytykę powabu posuwa tak dalece, że odmawia mu nawet pomocniczej roli przy ocenie piękna. Kolor nie powinien być według niego podnietą dla naszego zainteresowania czystym pięknem. W taki sposób mogą postępować jedynie ludzie niewykształceni, u których „smak jest jeszcze surowy i niewyrobiony" ${ }^{13}$. Dla ludzi obytych ze sztuką oczywiste jest, że powab często stoi w sprzeczności z pięknem i mieszanie ich ze sobą jest błędem. Na koniec zaś wyraźnie zauważa, że w malarstwie to rysunek, a nie kolor jest istotny przy wydawaniu czystego sądu smaku. Barwa może być tylko dodatkiem, który służy do tego, by wzmocnić linie i dopełnić rysunek. Kant odmawia zatem barwom nawet wartości oczarowywania widza. Jest to bowiem fałszywe oczarowanie, mogące oddalać nas od właściwej kontemplacji pięknej formy, a cieszyć tylko tych, którzy nie potrafią właściwie patrzeć na sztukę i błędnie zachwycą się materią przedstawienia, zapominając o warstwie formalnej dzieła.

W malarstwie, rzeźbie, ba, we wszystkich sztukach plastycznych, w architekturze i sztuce ogrodniczej, jeśli są one sztukami pięknymi, tym, co

12 Ibidem, s. 93-94.

13 Ibidem, s. 95. 
istotne, jest r y s u n e k, w którym podstawa, na której opiera się smak, nie jest coś, co sprawia zadowolenie przy odczuciu, lecz tylko to, co się podoba dzięki swej formie. Kolory, które iluminują zarys rysunku, przynależą do powabu. Co prawda mogą one czynić przedmiot sam w sobie żywszym dla czucia, ale nie mogą uczynić go ani godnym oglądania, ani pięknym. Same raczej ulegaja, i to często w bardzo wysokim stopniu, ograniczeniu przez to, czego wymaga piękna forma. I nawet tam, gdzie powab zostaje dopuszczony, uszlachetniać go może tylko piękna forma ${ }^{14}$.

Trzeba jednak wyraźnie zaznaczyć, że pod koniec XVIII wieku Kant miał w tej kwestii już kilku zagorzałych oponentów, spośród których do najważniejszych należałoby zaliczyć Denisa Diderota i Johanna Wolfganga Goethego. Jednakże wątpliwości dotyczące prymatu rysunku nad kolorem zaczęły się dużo wcześniej. Powróćmy zatem do teoretycznych rozważań końca XVII wieku rozgrywających się w Królewskiej Akademii Malarstwa i Rzeźby.

Siódmego maja 1667 roku serię publicznych referatów rozpoczął Charles Le Brun i to on nadawał zasadniczy ton wszystkim dyskusjom. Nic dziwnego, jest on jedną z najznamienitszych osobowości francuskich tamtych czasów. Znakomity malarz i rysownik, znawca malarstwa, a przede wszystkim autor rozważań teoretycznych dotyczących sztuki, znany ze swojego znakomitego dzieła dotyczącego fizjonomiki artystycznej De l'expression générale et particulière ( $O$ ekspresji ogólnej i szczegótowej 1668) ${ }^{15}$. Pominę tutaj szczegółowe informacje dotyczące omawianych przez niego obrazów, pragnę jedynie przypomnieć ogólny schemat ich analiz. Porusza on następujące kwestie: układ dzieła (kompozycja), rysunek i proporcje, wrażenia emocjonalne wywoływane przez poszczególne postacie bądź grupy postaci, układ perspektywy linearnej i powietrznej, ogólna harmonia dzieła. Zwróćmy uwagę, że na kwestie koloru nie ma tutaj $w$ ogóle miejsca. Zagadnienia te pojawiają się co prawda marginalnie, w połączeniu $\mathrm{z}$ harmonia, fizjonomiką i kolorytem skóry, oddaniem emocji postaci, a przede wszystkim przy rozważaniach dotyczących perspektywy powietrznej, osłabianie intensywności koloru w miarę oddalania się kolejnych planów itp. Takie podejście nie było w tamtych czasach czymś wyjątkowym. Generalnie kolor pełnił kilka funkcji i tylko tak był rozpatrywany przez teoretyków.

Po pierwsze: kolor służył do tego, by rozróżniać od siebie przedmioty i by móc je zidentyfikować. Jest to kwestia techniczna, która pozwala artyście odgraniczyć od siebie poszczególne partie obrazu i uczynić je rozpoznawalnymi dla odbiorcy. Po drugie: kolor jest środkiem imitacji natury. Dobry naśladowca, jakim jest malarz, musi wiernie oddawać

14 Ibidem, s. 95-96.

15 Zob. [Charles Le Brun] O ekspresji ogólnej i szczegółowej, w: Teoretycy, historiografowie i artyści o sztuce 1600-1700, op. cit., s. 545-553. 
naturę. Gdyby artysta nie był wierny naturze, tylko by się ośmieszył przed publicznością, która wychwyciłaby różnice i uznałaby je za braki w technicznych umiejętnościach twórcy. Przede wszystkim zwracano tu uwagę na karnację przedstawianych postaci i umiejętność oddawania emocji na ludzkich twarzach. Po trzecie: kolor jest potrzebny po to, by móc oddać perspektywę powietrzną która dużo plastyczniej i realniej imituje naturę niż perspektywa liniowa. Wszystkie te uwagi pojawiają się jednak jakby mimochodem przy omawianiu ważniejszych kwestii związanych z perspektywą czy oddaniem wieku, pozycji społecznej bądź też emocji poszczególnych postaci. Występują one zwłaszcza przy omawianiu obrazów Tycjana, zawsze jednak z takim komentarzem jak w przemówieniu Philippe'a de Champaigne, że:

Najważniejszym dziełem malarstwa jest poprawność i trafność proporcji i jej winno się przede wszystkim poświęcać. Wszyscy zgodni są co do tego, że mało jest malarzy poprawnych w rysunku, wielu zaś pięknie poczyna sobie z farbami [...]. Nie mówię, że jest to dział niepotrzebny, ale poświęcać mu więcej uwagi niż sprawie głównej i czynić z niego jedyny przedmiot studiów - to oszukiwać siebie ${ }^{16}$.

Zasadnicza dyskusja nad rolą koloru rozpoczęła się wraz z publikacjami Rogera de Piles, o których będzie mowa dalej. Zanim jednak to nastąpiło, w listopadzie 1671 roku, pod nieobecność Le Bruna, malarz i członek Królewskiej Akademii Gabriel Blanchard wygłosił przemówienie $O$ zastugach koloru, w którym postawił trzy główne tezy. Po pierwsze: kolor w sztuce malarskiej jest tak samo ważny jak rysunek. Po drugie: obniżając wagę koloru, deprecjonuje się rangę malarza. Po trzecie: kolor był ważny już dla starożytnych, więc i dla nas powinien być istotny. Argumenty, których używał, były te same, jakie stosowali Le Brun, Félibien czy Poussin, ale tym razem odwrócił ich ostrze w taki sposób, by broniły kolorystów. Twierdził mianowicie, że malarstwo to sztuka, której działanie polega na tworzeniu doskonałej imitacji natury, a bez umiejętności właściwego używania koloru nie sposób właściwie oddać rzeczywistości. Ponadto sam Stwórca tak urządził świat, by mienił się różnymi kolorami, a zatem artysta nie może wstydzić się dzieła Bożego. To prawda, zauważa, że rysunek podoba się znawcom, a barwa także osobom niewykształconym, jednak warto, by jak największe grono odbiorców podziwiało dzieło sztuki. Należy też zwrócić uwagę na to, że kolor jest cechą charakterystyczną właśnie dla malarstwa, odróżniającą

16 Wystąpienie Champaigne wg antologii: A. Lhote, De la palette à l'écritoire, Paris 1946, s. 66. Cyt. za: M. Rzepińska, Historia koloru w dziejach malarstwa europejskiego, t. 1, rozdz. VIII, op. cit., s. 363. 
je od innych dziedzin sztuki, podczas, gdy rysunek właściwy jest także rysownikom i architektom ${ }^{17}$.

Być może argumenty te zostałyby nawet zaakceptowane, bo w znacznej mierze wpisywały się ogólne rozważania o sztuce. Jednak zadziałał tu przypadek. W tym samym roku została powołana Akademia Architektury, którą chciano połączyć z Akademią Malarstwa i Rzeźby. Zamiast podkreślić różnicę między sztukami chciano zaakcentować ich podobieństwa. Trzeba więc było ponownie wydobyć wagę rysunku i w tym celu przypuszczono atak na teorię Blancharda, w którym pierwsze skrzypce grał Le Brun ${ }^{18}$.

Przede wszystkim Le Brun twierdzi, że rysunek wystarczy do tego, aby oddać wszystkie namiętności duszy i kolor w niczym nie jest tu potrzebny. Biorąc pod uwagę jego słynne, wspominane już tutaj, dzieło O ekspresji ogólnej i szczegótowej, opatrzone olbrzymią liczbą szczegółowych rysunków, można przyznać mu w tym punkcie rację. Jednak rysunek pozostaje rysunkiem, a nie jest malarstwem, to bowiem wymaga koloru. Z kolorem wiąże się jednak kilka problemów, z których głównym jest postrzeganie go w sposób subiektywny. Na gruncie XVIII-wiecznej fizyki, pomimo osiągnięć Newtona, trudno bowiem jednoznacznie stwierdzić, że rzeczy w naturze mają jakieś obiektywne kolory, niezależne od obserwatora, oświetlenia, odległości oraz kontrastów towarzyszących im barw innych przedmiotów. Dlatego też kolor - twierdzi Le Brun, zgodnie ze specyficznie przez siebie interpretowaną filozofią Arystotelesa - jest cechą akcydentalna, przypadkową a zatem nawet najznamienitszy malarz nie ma możliwości oddania prawdy o rzeczywistości. Ponadto kolor w malarstwie jest tylko materia, z której artysta tworzy, dopiero nadając mu pewną formę. To rysunek decyduje o miejscu barwy na obrazie, to on odpowiada za układ całości, i jako taki ma moc duchową a nie zmysłową. Kolor pełni zatem służebną funkcję wobec rysunku. W ostateczności malarz francuski dochodzi do wniosku, że bez rysunku nie istnieliby malarze, bo sam kolor nigdy nie jest twórczy ${ }^{19}$.

Sytuacja zmienia się diametralnie w 1673 roku, za sprawą Rogera de Piles, pisarza, dyplomaty i prawnika, który nie był członkiem Akademii, choć parał się także malarstwem i grafiką. Jeszcze przed wspomnianym rokiem 1673 cieszył się sporą sławą za sprawą znakomitego przekładu rozprawki Karola Alfonsa Dufresnoy De arte graphica (1688),

17 Informacje za M. Rzepińska, Historia koloru w dziejach malarstwa europejskiego, t. 1, rozdz. VIII, op. cit., s. 363-364.

18 Ibidem, s. 364. Por. też: B. Teyssédre, Roger de Piles et les débats sur le coloris au siècle de Louis XIV, Paris 1965, s. 175-176.

19 Dokładną relację z wykładu wygłoszonego przez Le Bruna można znaleźć w: M. Rzepińska, Historia koloru w dziejach malarstwa europejskiego, t. 1, rozdz. VIII, op. cit., s. 364-365. 
którą zaopatrzył w dodatek zatytułowany Dialoque sur la coloris ${ }^{20}$. Dodatek ten jest pierwszą publikacją w całości poświęconą zagadnieniom koloru. Autor postuluje w nim przede wszystkim połączenie nauki o światłocieniu z umiejętnością zastosowania kolorytu. Do tej pory światłocień traktowany był raczej jako element rysunku, zapewne dlatego, że w obu tych środkach artystycznych łatwiej o wyłożenie zasad w sposób naukowy. Francuski intelektualista doskonale zdawał sobie sprawę z tego, że największa niechęć do koloru bierze się stąd, iż jest to wiedza nieuregulowana, oparta raczej na naśladownictwie niż na ścisłych regułach. $\mathrm{Z}$ tego powodu jego publikacje to $\mathrm{w}$ znacznej mierze próba pokazania, że możemy wypracować ścisłe zasady także w przypadku stosowania braw, choć jednocześnie zauważał, iż najlepiej uczyć się ich nie z podręczników, lecz z płócien największych mistrzów. Widać to wyraźnie w opublikowanej w 1708 roku rozprawie o zamiennym tytule Wykłady zasad malarstwa (Cours de Peinture par Principes):

Przyczyną tego [że mało jest kolorystów - K. K.] jest to, że rysunek ma reguły oparte na proporcjach, na anatomii i na dłuższym praktykowaniu tychże, gdy natomiast koloryt nie posiada dotąd w ogóle dobrze znanych reguł, a doświadczenie, jakie się [w tym zakresie] uzyskuje, a które jest zarazem inne z powodu różnorodności tematów, nie pozwoliło dotąd na ustalenie dokładnych zasad ${ }^{21}$.

Po kilku zdaniach pochwał na temat wiedzy o stosowaniu kolorów u Tycjana i Rubensa dodaje:

Zważywszy to, co powiedziałem o Tycjanie i Rubensie, ci, którzy chcą zyskać biegłość w kolorycie, nie mogą zrobić nic lepszego, niż oglądać obrazy tych dwóch wielkich mistrzów niczym publicznie [dostępne] księgi, które mogą dostarczyć im wiedzy. Trzeba tylko dobrze zanalizować ich dzieła, kopiować je przez jakiś czas, ażeby je dobrze zrozumieć i poczynić na ich temat te wszystkie uwagi, jakie się uzna za konieczne, ażeby na ich podstawie sformułować zasady ${ }^{22}$.

Roger de Piles zgodnie ze swoimi własnymi zaleceniami analizuje szereg dzieł nowożytnych, aby wydobyć z nich owe prawidła, na których należy oprzeć naukę o stosowaniu kolorów w malarstwie. Empiryczna wiedza odnaleziona u takich na przykład mistrzów jak Tycjan, Rubens i, co najciekawsze, Rembrandt pozwala mu sformułować kilka istotnych zaleceń.

20 Ibidem, s. 365.

21 R. de Piles, Cours de Peinture par Principes, Paris 1708, cytat za: Teoretycy, historiografowie i artyści o sztuce 1600-1700, op. cit., s. 601.

22 Ibidem. 
Po pierwsze: należy rozdzielić kolor naturalny od barwy sztucznej jako środka malarskiego, są to bowiem dwie różne rzeczy, jedna występuje $\mathrm{w}$ otoczeniu, a druga to próba stworzenia takiego zestawu odcieni, aby jak najdoskonalej oddać kolor naturalny. Nie należy przy tym zapominać, że nawet $\mathrm{w}$ przyrodzie mamy do czynienia $\mathrm{z}$ trojakim postrzeganiem kolorów, zależnym od prawdziwego koloru przedmiotu, koloru odbitego i koloru światła. Po drugie: w sztuce należy mówić nie tyle o kolorze, który rzeczywiście jest materia, ile o kolorycie, czyli rozumnej umiejętności zestawiania barw, o ich poszczególnych sympatiach i antypatiach oraz o światłocieniu ${ }^{23}$. Dzięki temu można dokonać odróżnienia pomiędzy rzemieślnikiem a malarzem, nie odwołując się do rysunku. Farbiarze znają się na kolorach, ale już nie na zestawianiu kolorów i dlatego nie są artystami. Z tego samego powodu przyznaje rangę artystów twórcom gobelinów. Po trzecie: wiele uwagi poświęca opisaniu poszczególnych zasad malarskiego stosowania barw, bardzo często odwołując się do materii muzycznej. Porównuje sympatie i antypatie barw do zgodności i niezgodności dźwięków, pisze o chromatyce barw, o akordach kolorów, o zdolności niektórych kolorów do wchodzenia $\mathrm{w}$ interakcje $\mathrm{z}$ innymi albo o barwach, które zawsze pozostają w opozycji do innych ${ }^{24}$. Jednocześnie zwraca uwagę na to, że dotąd teoretycy nie spróbowali nawet wypracować odpowiedniej terminologii i nie potrafili dostrzec zasad prawidłowego zestawiania barw. Być może ten ostatni fakt spowodował, że francuski estetyk zmuszony był do poszukiwania pojęć w dziedzinie muzykologii, jednocześnie prowadząc do tego, że i dziś chętnie znajdujemy w obu dziedzinach pokrewieństwa chociażby tylko frazeologiczne.

Autor pierwszej teorii koloryzmu nie pozostawia wątpliwości. Zadaniem malarza jest odtwarzanie rzeczywistości, którą postrzegamy właśnie dzięki waloryzacji kolorystycznej. Kolory zaś odtwarza tylko malarz, nie zaś rzeźbiarz, rysownik czy grafik. To prawda, że dla malarza istotny jest rysunek, stanowi on podstawę oddania proporcji, perspektywy, stosunków między rzeczami. Artysta może dzięki niemu odtwarzać wszystko to, co mierzalne, stosunki ilościowe. Dla de Piles rysunek jest początkiem warsztatu malarskiego, szkieletem przyszłego obrazu, pewnego rodzaju konstrukcją pomocnicza, imaginacyjną, wynikającą ze zdolności intelektualnej autora, a nie z doświadczenia bezpośredniego otaczającej rzeczywistości. Widać to wyraźnie przy krytyce malarstwa Poussina, jaką przeprowadza de Piles w Abrégé de la vie des peintres (Skrót żywotów malarzy.... 1699). Zdolności kompozycyjne francuskiego malarza są fenomenalne, olbrzymia praca nad optyką i perspektywa, dogłębne studia nad rzeźbą starożytną doprowadziły do genialnego budowa-

23 Por. ibidem, s. 596-597.

24 Por. ibidem, s. 598-599. 
nia układu obrazu. Jednak kolor szwankuje. Nie mógł go Poussin odkryć u starożytnych, zatem musiałby posiłkować się naturą. Tego jednak nie uczynił, sięgnął po inny wzorzec, po obrazy Tycjana. Powtarzając jego zasady kolorystyczne, potrafi uczynić swoje dzieła znośnymi.

Toteż większość jego [Poussina - K. K.] obrazów wygląda szaro i wydaje się nam pozbawiona siły i efektu [...]. Jeśli się jednak sprawę pogłębi, stwierdzi się, że cokolwiek jest tam dobrego w dziedzinie koloru, pochodzi raczej z pamięci o obrazach Tycjana, które kopiował, niż ze zrozumienia zasad tego weneckiego mistrza ${ }^{25}$.

Pomiędzy wspominanymi już Dialogiem o kolorach a Wykładami o zasadach malarstwa Roger de Piles publikuje jeszcze Première conversation sur la peinture (1676), gdzie zdecydowanie twierdzi, że to kolor stanowi główną zaletę obrazu malarskiego, to on wabi i przyciąga ludzkie zainteresowanie, także wówczas, gdy wiedza o sztuce jest niewielka. Obie pierwsze pozycje wywołały falę dyskusji i krytyki. Dyskutowane były powszechnie, co ciekawe, nie tylko w salach Akademii czy w kręgach artystycznych, ale także wśród zwyczajnych obywateli. Miało to zasadnicze znaczenie dla rozwoju koloryzmu. Początkowo w Królewskiej Akademii koncepcja ta była krytykowana, jednak powoli stanowisko to się zmieniało. Dyskusje publiczne spowodowały, że coraz częściej zaczęto interesować się zagadnieniami koloru oraz używać nowych terminów koniecznych $\mathrm{w}$ tych debatach. Jednakże nikt $\mathrm{w}$ tamtych czasach nie wpadł na pomysł, że w kolorze może drzemać ekspresja. Sposób oddawania emocji był kwestią rysunku, czyli pozy, mimiki, gestykulacji.

\section{Bibliografia}

Batteux C., Les Beaux-Arts réduits à un même principe, Paris 1989.

Burke E., Dociekania filozoficzne o pochodzeniu naszych idei piękna i wzniostości, przeł. P. Graff, Wydawnictwo PWN, Warszawa 1968.

Europejskie źródła myśli estetyczno-literackiej polskiego oświecenia. Antologia wypowiedzi pisarzy francuskich, niemieckojezycznych i angielskich 1674-1810, oprac. T. Kostkiewicz i Z. Goliński, Wyd. Naukowe Semper, Warszawa 1997.

Goldstein C., Studies in Seventeeth Century French Art Theory and Ceiling Painting, „Art Bulletin” 1965, vol. 47, nr 2, s. 231-256.

25 R. de Piles, Abrégé de la vie des peintres, avec des reflections sur leurs ouvrages, et un Traité du Peintre parfait de la Connoissance des Dessins, et l'utilité des Estampes, Paris 1699, s. 477-481. Cytat za: Roger de Piles, Skrót żywotów malarzy, z uwagami o ich dziełach, traktatem o doskonatym malarzu, o znawstwie rysunków i o użyteczności rycin, w: Teoretycy, historiografowie i artyści o sztuce 1600-1700, op. cit., s. 584-585. 
Hogarth W., Analiza piękna, przeł. M. Lachman, Wydawnictwo słowo/obraz terytoria, Gdańsk 2008.

Kant I., Krytyka władzy sadzenia, przeł. M. Żelazny, w: I. Kant, Dzieła zebrane, t. IV, Wydawnictwo UMK, Toruń 2014.

Kaśkiewicz K., Wpływ francuskich estetyków naturalistycznych osiemnastego wieku na klasyczna estetyke niemiecka, Wydawnictwo Naukowe UMK, Toruń 2010.

Lhote A., De la palette à l'écritoire, Paris 1946.

Piles de R., Abrégé de la vie des peintres, avec des reflections sur leurs ouvrages, et un Traité du Peintre parfait de la Connoissance des Dessins, et l'utilité des Estampes, Paris 1699.

Piles de R., Cours de Peinture par Principes, Paris 1708.

Rzepińska M., Historia koloru w dziejach malarstwa europejskiego, Wydawnictwo Arkady, Warszawa 1989.

Teoretycy, historiografowie $i$ artyści o sztuce 1600-1700, oprac. J. Białostocki, red. M. Poprzędzka, A. Ziemba, Wydawnictwo Naukowe PWN, Warszawa 1994.

Teyssédre B., Roger de Piles et les débats sur le coloris au siècle de Louis XIV, Paris 1965.

\section{Streszczenie}

Spór dotyczący ważności różnych środków wyrazu artystycznego rozegrał się dosyć niespodziewanie na spotkaniach w Królewskiej Akademii Malarstwa i Rzeźby w Paryżu pod koniec XVII wieku. Jednak jego konsekwencje miały swe echa jeszcze sto lat później, także w rozważaniach estetyki filozoficznej u takich jej twórców, jak: Denis Diderot, Johann Wolfgang Goethe, a nawet Immanuel Kant. Od 1667 roku w Królewskiej Akademii Malarstwa i Rzeźby rozpoczęto szeroko zakrojony program spotkań, gdzie referowano teoretyczne aspekty sztuki, a także omawiano konkretne dzieła, później przygotowane do druku przez André Félibien. Jednym z podstawowych celów Akademii było wykazanie, że ranga malarzy, grafików i rzeźbiarzy jest równie wysoka jak poetów i muzyków, że wszyscy ci artyści są czymś więcej niż rzemieślnikami. Wszystkie te gałęzie sztuki łączy rysunek, jako kompozycja może być podstawą przyjęcia malarstwa, grafiki i rzeźby do dziedziny sztuki, a nie rzemiosła, wymagają one bowiem przede wszystkim pracy intelektualnej, a dopiero $\mathrm{w}$ drugim rzędzie umiejętności praktycznych. Sytuacja zmienia się diametralnie w 1673 roku za sprawą Rogera de Piles. Autor twierdzi, że w sztuce należy mówić nie tyle o kolorze (który rzeczywiście jest materią), ile o kolorycie (czyli rozumnej umiejętności zestawiania barw), dzięki temu mógł dokonać rozróżnienia pomiędzy rzemieślnikiem a malarzem, nie odwołując się do rysunku.

Słowa kluczowe: Akademia Francuska, kolor, koloryt, rysunek, Roger de Piles 


\section{Summary}

\section{First Considerations on Colour in France at the Turn of the 17th and 18th Centuries}

A dispute concerning the importance of various artistic devices arose unexpectedly as a result of meetings held in the Royal Academy of Painting and Sculpture in Paris at the end of the 17th century. Its consequences, however, reiterated 100 years later in considerations on philosophical aesthetics in works by authors such as Denis Diderot, Johann Wolfgang Goethe, or even Immanuel Kant. In 1667, in the Royal Academy of Painting and Sculpture, a wide-ranging program of meetings was initiated in order to discuss theoretical aspects of art as well as comment on particular works later prepared for printing by André Félibien. For the Academy, one of the main aims was to prove that the status which painters, graphic artists, and sculptors enjoyed was comparable to that achieved by poets and musicians and that all the above mentioned artists are more than mere craftsmen. Drawing is the common point to all these fields of art and as s composition can justify the recognition of painting, graphics, and sculpture as art rather than craft since these primarily require intellectual work, then skills. The situation drastically changed in 1673 due to Roger de Piles who claimed that in art colouration (or a well-developed colour-matching skill) not colour itself is the key issue. Owing to that he was able to differentiate between a craftsman and an artist without referring to a drawing.

Keywords: French Academy, colour, colouration, drawing, Roger de Piles 